\title{
Sustainable diets: definition, state of the art and perspectives for a new research agenda in Brazil
}

\author{
Dietas sustentáveis: definição, estado da arte e perspectivas \\ para uma nova agenda de pesquisa no Brasil
}

Rozane Márcia Triches (https://orcid.org/0000-0002-4460-4821) ${ }^{1}$

${ }^{1}$ Programa de PósGraduação Stricto Sensu em Agroecologia e Desenvolvimento Rural Sustentável, Universidade Federal da Fronteira Sul. Rua Edmundo Gaievski 1000, Centro. 85770-000 Realeza PR Brasil. rozane.triches@gmail.com

\begin{abstract}
It is an integrative literature review to discuss the emergence and construction of the definition of sustainable diets, to bring the current panorama of what has been studied about it and to point to a new research agenda in Brazil. The searches conducted between April and July 2018, were carried out in the databases Science Direct, Pubmed, Periódicos Capes, Google Academic, Banco de Teses, in addition to the use of the method snowball, reaching 365 articles analyzed. The concern with sustainable diets is related to the redirection of the dominant food system in the achievement of environmental and health goals, considering the culture and the economy. The main focus of the articles were: theoretical efforts to conceptualize what are sustainable diets; analysis of different types of diets; factors involved in consumers' choices/behaviors; size of food production; of health; of the economy; culture and society; policies and governance; and discussion on the methodologies used to measure and analyze the different aspects of sustainable diets. In Brazil, only 19 papers were found, which points to the gap in this area of research and the need to create this agenda of studies in the country, given its importance for public and environmental health. Key words Food, Sustainability, Diets, Public health, Food system
\end{abstract}

Resumo Trata-se de revisão de literatura integrativa para discutir o surgimento e construção da definição de dietas sustentáveis, trazer o panorama atual dos estudos sobre o tema e apontar para uma nova agenda de pesquisa no Brasil. As buscas foram realizadas entre abril e julho de 2018, nas bases de dados Science Direct, Pubmed, Periódicos Capes, Google Acadêmico, Banco de Teses, além do uso do método snowball, resultando em 365 artigos analisados. A preocupação com dietas sustentáveis está relacionada ao redirecionamento do sistema alimentar dominante no alcance de metas ambientais e de saúde, considerando a cultura $e$ a economia. Os principais focos de interesse dos artigos foram: esforços teóricos para conceituar o que são dietas sustentáveis; análise de diferentes tipos de dietas; fatores intervenientes nas escolhas/ comportamentos dos consumidores; dimensão da produção de alimentos; da saúde; da economia; da cultura e sociedade; politicas e governança; $e$ discussão sobre as metodologias utilizadas para medir e analisar os diferentes aspectos das dietas sustentáveis. No Brasil foram encontrados apenas 19 trabalhos, dentre os quais, nove artigos, o que aponta para a lacuna nesta área de pesquisa e a necessidade de criar esta agenda de estudos no país, dada sua importância para a saúde pública e ambiental.

Palavras-chave Alimentação, Sustentabilidade, Dietas, Saúde Pública, Sistema alimentar 


\section{Introduction}

The predominant food system has reached high levels of productivity, but its consequences have called into question its efficiency in relation to sustainability and the population's health. These consequences can be identified in the world and in Brazilian population through nutrition problems and noncommunicable diseases, social and economic issues associated with food production and environmental problems.

Regarding food and nutrition of the Brazilian population, the nutritional transition has been observed in the last decades, which is characterized by an increase of overweight and noncommunicable chronic diseases, also associated with a declining prevalence of undernutrition. In this context, obesity was consolidated as a nutritional issue associated with the high incidence of cardiovascular diseases, cancer and diabetes, thus influencing the morbidity and mortality profile of the populations. The latest data released by Brazilian Institute of Geography and Statistics $(\mathrm{IBGE})^{1}$ on the Brazilian Household Budget Survey (2008-2009) indicate that around $50 \%$ of the adult population and one third of the child population are overweight.

With regard to production, a productive model has been strengthened in the last decades, which disseminates practices and offers types of food that are closely linked to this health scenario. This model is based on intensive, mechanized agriculture, with increased use of chemicals and food processing, long supply chains, standardization of food habits and with a great interference of the international trade in the domestic food supply. Its influences do not only concern food and nutrition issues, but also environmental and social consequences, such as the marginalization of a large numbers of family farmers and the unsustainable use of natural resources ${ }^{2,3}$.

According to the Sustainable Development Indicators $^{4}$ by IBGE, Brazil is among the ten largest emitters of greenhouse gases to the atmosphere and have other problems like: the destruction of natural vegetation, especially the Amazon deforestation and burning in the Cerrado; the deforested area accounts for almost $20 \%$ of the original Amazon forest area; lack of basic sanitation remains a serious socio-environmental problem, also causing alarming rates of contamination of rivers by household and industrial effluents; and the number of Brazilian species threatened with extinction has been increasing, which demonstrates the destruction of natural areas.
Considering that in the medium and long terms, food systems will be under pressures such as population growth, climate change, increased competition for natural resources, urbanization and globalization of diets, and that many of their effects will be negative, it is essential that strategy makers ponder the consequences of all these factors of change regarding their own food systems ${ }^{5,6}$. In the Brazilian case, this concern is even more emblematic, since all the aspects mentioned above would be aggravated and the efforts made to leave the Hunger Map could be lost.

Studies go further into this matter as the current food production system accounts for 20 to $30 \%$ of greenhouse gas emissions; about $24 \%$ of the arable land has some type of soil degradation depending on the agricultural model adopted; the use of land for monoculture and livestock farming has led to deforestation and loss of much of the biodiversity; and water has been contaminated, including sea water, leading to imbalances in the marine environment. However, not only does food production generate environmental problems, but also the processes included in the supply chain, such as transport, processing and preparation of food, as well as wastage and waste generated $^{7-9}$.

Given this context, it is necessary to rethink the consumption of food and especially the diets. What and how much we eat impacts directly on what and how much we produce, and therefore it is necessary that diets be more sustainable and also healthy. In Brazil, the field of Nutrition and even other areas of knowledge have not explored this type of approach yet and barely addresses matters related to the agri-food model and its influence on Brazilian people's diets and vice versa.

Given the importance of this theme and the need to bring the discussion of sustainable diets to Brazil (so that the academy can subsidize policies and actions that meet the problems mentioned above), this article proposes, based on existing literature: i) to discuss the emergence and construction of the definition of sustainable diets; ii) to provide the current panorama of what has been studied on this topic worldwide and iii) to point out a new research agenda in Brazil.

\section{Methodology}

This research is characterized as an integrative literature review. This type of review enables analyses that extrapolate the synthesis of the results of the primary studies, covering other di- 
mensions of the research, and has potential for the development of new theories and research problems ${ }^{10}$. It was composed of six phases in the elaboration process: elaboration of the guiding question (what are sustainable diets and what has been studied about it?), literature search, data collection, critical analysis of studies and enclosed documents, discussion of data and presentation of the integrative review.

Based on the guiding question, criteria for the selection of studies and search strategy were defined. The searches were carried out in the Science Direct, Medline/ Pubmed, Periódicos Capes, and Google Academic databases (uniterms in English) and SciELO and Banco de Teses da Capes databases (uniterms in Portuguese). In addition, the snowball method was used, which consists in reviewing the references used in the studies found when searching the databases.

Uniterms 'sustainable diet' were used in English and Portuguese, in singular and plural forms, and full articles published in English/ Portuguese with no limit for date of publication, country of study or area of knowledge were included. Articles that did not explicitly address the issue, did not answer the research question and those that were editorial were excluded. Therefore, the title and abstract of the publications were read and the studies that did not meet the research requirements were removed. Papers published in Brazil, in Portuguese language, were analyzed separately to obtain a clearer view of what has been studied in the country.

Afterwards, the documents were fully analyzed to explore the objectives of the study, the methodology used and the results, by seeking to identify and systematize what has been studied within the sustainable diets theme and how this theme has been developing in recent years. This search was conducted between April and July 2018.

\section{Results and discussion}

\section{State of the art review on sustainable diets}

By analyzing the number of published studies using the term 'sustainable $\operatorname{diet}(\mathrm{s})$ ' at some point in their body, we found that this theme has gained prominence over the last eight years, as can be seen in Table 1. By searching major databases, the following amount of published articles were found: 1805 in Google Scholar, 368 in Science Direct, 346 in Periódicos Capes, 75 in
Pubmed, 72 in Bireme. With the snowball method another 124 records were found. The total was 2790 materials, but of these, 809 were duplicates and 1616 were excluded after screening by exclusion criteria. The final number of 365 articles was obtained, written mainly after 2010, as Graphic 1 shows.

These 365 articles were mostly developed by European researchers, especially in the United Kingdom (77 articles) which, together with the Atlantic countries of Northern Europe, is the region that has most published research on sustainable diets (Graphic 2). The region with the second largest number of publications, also in Northern Europe but connected to the Atlantic Ocean through the North Sea, includes Netherlands, Belgium and Germany, out of which the Netherlands is the most prominent, with 52 published articles. In Latin America there were nine articles, five of them from Brazil, one from Argentina, one from Chile, one from Peru, and one from Uruguay.

According to the literature and by seeking to organize the information, nine main foci of studies on sustainable diets were formulated: 1) theoretical efforts to conceptualize and discuss what sustainable diets are; 2 ) analysis of different types of diets, meals, culinary preparations, foods and nutrients and their interrelations, mainly with the environment dimension, but also with other dimensions; 3) consumption - factors that intervene in consumers' choices/behaviors and which recommendations or dietary guidelines are formulated by countries to try to guide them towards sustainable diets; 4 ) the agriculture dimension, or the food production dimension - how food has been produced, processed, transported, wasted; 5) health dimension; 6) economic dimension; 7) socio-cultural dimension; 8) policies and governance related to sustainable diets and the food system; 9) discussion about the methodologies used to measure, analyze, and evaluate the different aspects of sustainable diets. These foci can be seen in Table 2 .

\section{Understanding what sustainable diets are}

Given the number of studies found, firstly we sought to identify how the concept of sustainable diets has been constructed. The first publication to use the term sustainable diets was written by Gussow and Clancy in 1986, published in the Journal of Nutrition Education with the title "Dietary Guidelines for Sustainability" ${ }^{11}$. The authors argued that it was no longer sufficient for 
Table 1. Number of published articles including the term 'sustainable diet(s)' in bibliographic databases from 1970 to 2018.

\begin{tabular}{lrcrr}
\hline $\begin{array}{c}\text { Data base Publication } \\
\text { Years }\end{array}$ & Capes & Pubmed & Science Direct & Google Schoolar \\
\hline $1970-1980$ & 0 & 0 & 0 & 0 \\
$1981-1990$ & 1 & 0 & 5 & 3 \\
$1991-2000$ & 9 & 0 & 24 & 26 \\
$2001-2010$ & 26 & 3 & 44 & 196 \\
$2011-2018$ & 310 & 84 & 295 & 1580 \\
Total & 346 & 87 & 368 & 1805 \\
\hline
\end{tabular}

Source: The authors.

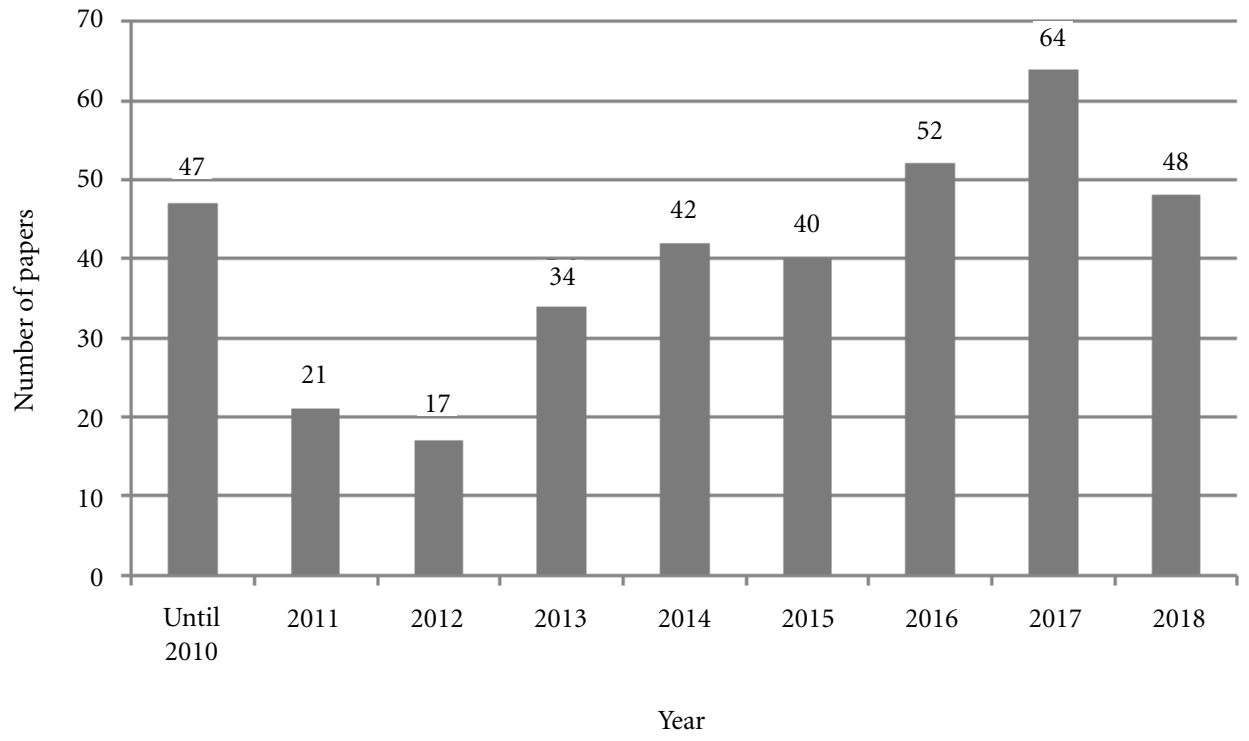

Graphic 1. Number of papers until 2018 on sustainable diets.

nutrition education to provide information on the relationship between human health and food choices because educated consumers needed to make dietary choices that not only improved their own health but also contributed to the protection of natural resources. Thus, they suggested the term 'sustainable diets' by relating it to 'sustainable agriculture', given that sustainability would be associated with anything able to remain within natural systems in the foreseeable future. Thus, sustainable agriculture is agriculture that uses human and natural resources to produce food and fiber in a preservative way, that is, in a way that does not waste finite resources such as soil, water and fossil fuel. In another study published in 1989 by Herrin and Gussow ${ }^{12}$, the authors propose to discuss a sustainable regional diet, advocating the idea of consumption of locally produced foods.

In the 1990s, Feenstra $(1997)^{13}$ and Peters $(1997)^{14}$ took up the idea that building a sustainable and secure food system begins by reconnect- 
Graphic 2. Number of articles published by world regions on sustainable diets.

Table 2. Systematization of the articles found in nine foci of study and their respective subdivisions on sustainable diets until 2018.

\begin{tabular}{|c|c|c|}
\hline Research Focus & Subdivisions of themes within each study focus & $\begin{array}{c}\text { Publications } \\
\text { number }\end{array}$ \\
\hline \multirow[t]{2}{*}{ Theory } & Publications about theoretical discussions on sustainable diets & \\
\hline & Total & 22 \\
\hline \multirow[t]{14}{*}{ Diet } & Mediterranean & 14 \\
\hline & Vegan/vegetarian/ovo-lacto vegetarian & 14 \\
\hline & Diets of the emerging contries (Argentina, Brasil, China, Índia etc.) & 11 \\
\hline & Nordics & 8 \\
\hline & Dutchs & 8 \\
\hline & Other types of the diets/menus & 46 \\
\hline & Analyse of the deals e recipes & 5 \\
\hline & Consumption meat & 24 \\
\hline & Consumption dairy & 10 \\
\hline & Other foods & 17 \\
\hline & Proteins & 5 \\
\hline & Calories, fats & 7 \\
\hline & Micronutrients and others substancies & 6 \\
\hline & Total & $146^{*}$ \\
\hline \multirow[t]{6}{*}{ Consumption } & Perceptions, beliefs, ideals, motivations, preferences & 29 \\
\hline & Behavior, lifestyles, habits, tastes & 20 \\
\hline & Awareness, information, knowledge, education & 8 \\
\hline & $\begin{array}{l}\text { Demographic and psychological characteristics (gender, socioeconomic } \\
\text { level, age) }\end{array}$ & 7 \\
\hline & Strategies and interventions (dietary guidelines) & 21 \\
\hline & Total & $72^{*}$ \\
\hline
\end{tabular}


Table 2. Systematization of the articles found in nine foci of study and their respective subdivisions on sustainable diets until 2018.

\begin{tabular}{|c|c|c|}
\hline Research Focus & Subdivisions of themes within each study focus & $\begin{array}{c}\text { Publications } \\
\text { number }\end{array}$ \\
\hline \multirow[t]{9}{*}{ Agriculture } & Livestock (meat, dairy, fish, eggs etc.) & 16 \\
\hline & Local, regional, transport and supply & 11 \\
\hline & Diversification and sazonality & 10 \\
\hline & Organics & 10 \\
\hline & Waste & 9 \\
\hline & Processing and development of the news products & 5 \\
\hline & Pesticides and fertilizers & 1 \\
\hline & Others (vitiviniculture, rural tourism, soil) & 3 \\
\hline & Total & $63^{*}$ \\
\hline \multirow[t]{5}{*}{ Health } & Noncommunicable diseases & 2 \\
\hline & Obesity & 3 \\
\hline & Nutrition & 2 \\
\hline & Nutritional deficiencies & 2 \\
\hline & Total & $7^{*}$ \\
\hline \multirow[t]{5}{*}{ Economy } & Taxs, subsidies & 5 \\
\hline & Industry/retail/services & 4 \\
\hline & Prices, costs & 3 \\
\hline & Rebound effect & 2 \\
\hline & Total & 14 \\
\hline \multirow[t]{5}{*}{ Sociocultural } & Social actors & 3 \\
\hline & Community/social inclusion & 3 \\
\hline & Ethic/moral & 2 \\
\hline & Gourmet & 1 \\
\hline & Total & 9 \\
\hline \multirow[t]{3}{*}{ Policies e governance } & Policy & 9 \\
\hline & Governance & 2 \\
\hline & Total & 11 \\
\hline \multirow{4}{*}{$\begin{array}{l}\text { Metrics, measures } \\
\text { and models to analyse } \\
\text { sustainable diets }\end{array}$} & Life cycle analysis & 8 \\
\hline & Development of the others metrics and indexes & 8 \\
\hline & Analysis of the others existing metrics and indexes & 6 \\
\hline & Total & $21^{*}$ \\
\hline Total & & 365 \\
\hline
\end{tabular}

${ }^{{ }^{*}}$ The total number is less than the sum of the parts, since some studies have more than one focus of analysis.

Source: The authors.

ing local food systems with the construction of a healthy community, bringing attention to the term Environmental Nutrition. This is related to the idea that food choices have consequences and can make a difference in the way natural resources are used. Wahlqvist and Specht $(1998)^{15}$ use the term Econutrition to allude to the importance of food variety and biodiversity for health and the environment.

These authors and studies began a discussion in the 1980s and 1990s involving the relationship between diets and food systems, or between health and agriculture, which practically did not exist by then. Since the 2000s, studies on this have become more frequent, given the emergence of food problems, coupled with environmental, social and economic issues related to food. These issues have equipped several branches of science to seek a better understanding of the relationship between production and food consumption. Food production, which had been thought through the bias of productivism until then, starts to be discussed due to its consequences as an unsustainable model. On the other hand, 
food-related diseases have increased significantly, and the environment has been showing its limits, evidencing the need for changes in the population's eating habits and the consumerism culture. Thus, consumption and diets began to be thought as important links of a sustainable food system in a perspective where there is an interaction with other concepts, as sustainability, sustainable development, sustainable food consumption and sustainable nutrition.

Within this sustainability debate, in 2010, FAO coined the concept of 'Sustainable Diets':

They are those diets with low environmental impacts which contribute to food and nutrition security and to healthy life for present and future generations. Sustainable diets are protective and respectful of biodiversity and ecosystems, culturally acceptable, economically fair and affordable; nutritionally adequate, safe and healthy; while optimizing natural and human resources. ${ }^{16}$

However, for Meybeck and Gitz ${ }^{17}$, this definition does not involve the food system directly, and therefore the authors propose another definition:

A sustainable diet is a diet that contributes to good nutritional status and long term good health of the individual/community, and that contributes to, and is enabled by, sustainable food systems, thus contributing to long term food security and nutrition.

The authors argue that this concept explicitly links the two concepts and that it turns sustainable diets not only into a concept, but also into a goal: to transform the food system to achieve food and nutrition security. For Mason and Lang $^{18}$, the term refers both to health and environment and encapsulates a multiplicity of goals for healthy eating in order to cause the lowest environmental impact, which is aligned with other cultural and socioeconomic goals.

Combining these concepts and considering that a sustainable food system is based on four domains - health, economy, society and the environment ${ }^{19}$, sustainable diets interact with these dimensions when they are said to be culturally acceptable (social dimension), fair and affordable (economic dimension), safe, nutritious, and healthy (health dimension), protective and respectful of biodiversity and ecosystems (environment). In addition to these dimensions, the definition by FAO and other authors who have been studying this theme ${ }^{20,21}$ add agriculture as a fifth determinant or a fifth dimension.

In order to try to understand the complexity of what a sustainable diet is, according to the the- oretical articles found, these five dimensions or determinants must be understood as being interconnected, and by taking up some authors' arguments ${ }^{7,17-21}$, they correspond to a set of questions.

Therefore, the concept of sustainable diets suggests that they must be constituted to have the potential to recalibrate the current food system, for this system compromises the ability to produce food in the future and can have irreversible effects on the ecosystem and health.

\section{Studies on different types of diets and their components}

Out of the 365 articles found, 146 were directly related to the study of different diets and their compositions (meals, menus, preparations, foods, nutrients). All these articles, without exception, relate diets to the environmental dimension. The most commonly found analyses refer to gases emission or to a set of environmental factors assessed by the life cycle (compilation of evaluations of inputs, outputs and potential environmental impacts of a product system throughout its life cycle). However, there are studies focusing on certain environmental issues, such as the impact on land use (12 articles) and water use (five articles). It should be noted that the size of agriculture also appears implicitly when environmental analyses are carried out, referring to the environmental impact of production, transportation, processing, land use, water etc.

The other dimensions of sustainable diets are also considered in some studies, such as the health dimension, in which analyses aiming to identify the diets that best respond to nutritional quality coupled with environmental impact (46 articles) stand out. Works that added to the analyses including environment, health and economy totaled 14 articles, and there were five works which analyzed environment, health and the sociocultural dimension together. There were only five articles with analyses under scrutiny of all dimensions (health, environment, socio-cultural, agriculture, economic).

One of the most analyzed diets in the studies (14 articles), carried out mostly by Italians and Spanish researchers was the Mediterranean Diet, which is considered an example of a sustainable diet for its nutritional quality along with its low environmental impact, respect for culture and tradition and economic viability. Another group of diets evaluated in 14 studies included diets with reduced use of meat (e.g. plant-based diets) or no use of meat but including eggs and milk 
(e.g. ovo-lacto vegetarian diets) and diets which exclude any type of product of animal origin (e.g. vegetarian and vegan diets).

Some diets associated with specific consumption characteristics from each country or group of countries were also investigated. The Nordic and Dutch diets stand out, with eight studies each. Emerging countries like China, India, Brazil and Argentina have 11 articles in total. However, it should be noted that these studies are predominantly from Europe; out of the 53 articles with this focus, $33(62 \%)$ are from Europe. It is worth noting that some of these studies analyzed the nutritional recommendations of their country to compare them with the usual diets or with other dietary patterns, or they conducted modeling of diets which brought together nutrition and environment goals in optimal diets. In this regard, Behrens et $\mathrm{al}^{22}$ carried out an environmental impact analysis of the nutritional recommendations of 37 countries, identifying whether healthy diets are compatible with sustainable diets.

Within this dietary assessment, few studies (five) have been dedicated to the analysis of meals - homemade, semi-prepared, ready-to-eat, school snacks or specific preparations - identifying which ones impact more or less the environment.

On the other hand, the most assessed foods in the studies were meats and dairy products, considering their high impact on the environment. This largely explains the amount of analyses of diets such as vegan/vegetarian/plant-based/ Mediterranean, as explained above. Studies identifying the environmental impact of meat consumption total 24 articles, and analyses of the consumption of dairy products total ten articles. Considering the current interest in identifying the environmental impact of food, this research found seven studies performing this analysis with a broad range of foods. Ten other studies investigated specific foodstuffs, such as organics, compared to conventional foods, fish and seafood, beverages, fruits and vegetables, foods of a given region or culture, insects, and foods of low nutritional quality.

Regarding nutrients, the most recurrent topics of study are related to protein (five studies), due to the need to reduce/avoid the consumption of animal products, given their high environmental impact. Thus, alternatives to replace animal protein by other sources such as insects, plant proteins and cultured protein are studied. In addition to this nutrient, the study of sustainable diets has been suggesting that the alterna- tives also protect against cardiovascular diseases, since reducing meat consumption would also reduce the consumption of animal fats and, therefore, increase the consumption of vegetables and fruits. In these discussions between nutritional quality versus environmental impact, in addition to macro and micronutrient analysis, there is also room for research on chemical residues in food, which may cause endocrine disorders, various types of cancer and noncommunicable diseases. On the other hand, especially in studies focused on organics, phytochemicals have been included in the discussion as important substances for the prevention of those diseases.

\section{Consumption and sustainable diets}

One of the core topics of sustainable diets is the dietary patterns and foods we choose to make up our daily menu, but another important research question is to understand consumers' motivations/behaviors. Seventy-two articles seek to identify perceptions, beliefs, ideals, motivations, consumer preferences; their levels of awareness, information, knowledge, education; behaviors, different lifestyles, habits, tastes; and the demographic and psychological characteristics of people (gender, socioeconomic status, age), relating these aspects to acquisition or consumption of certain foods.

Some of these studies identify the consumer's profile, reasons and difficulties in adhering to diets considered to be more sustainable, such as less meat, fewer dairy products, with more environmentally-friendly food choices, organics, local products, and others. Therefore, they consider that one of the great challenges posed when consumers choose sustainable diets is their difficulty in changing behaviors and culturally acquired tastes, but also by other determinants such as lack of knowledge, motivation and affordable prices.

In this regard, strategies and interventions (21 articles) are also studied, which verify the effectiveness of training, messages, labels, actions in schools and experiments with decreasing portions of meat and increasing portions of vegetables in restaurants and military institutions, for example. Ten of these studies report the experiences of countries such as the United States, Qatar, United Kingdom, Italy and organizations (Double Pyramid, developed by the Barilla Center for Food \& Nutrition Foundation) in building population strategies based on nutrition actions, guidelines and guides adjusted to the precepts of sustainable diets. 


\section{Agriculture dimension - food production}

One of the dimensions which is implicit in the studies on sustainable diets is agriculture, given that one of the precepts of this theme is to add nutrition concerns to the existing food production model. Thus, in an attempt to systematize the articles found in this review, we tried to identify studies that focused on the environmental impact by considering the production aspect more than the consumption or the actual diets, as they were previously explored.

Thus, we grouped 63 articles which explored deeply issues related to local, regional, production (conventional/organic), livestock production, dairy production and other crops (fish farming, aquaculture, wine-making, heliciculture), land use, genetic selection, animal feed production, use of pesticides and fertilizers, animal welfare, transport (food miles), processing, development of new products, crop diversification, seasonality, self-consumption, rural tourism, insect breeding, wastage, and other related subjects.

Studies interested in discussing the location or shortening of the supply chain and its relationship with economy and food miles (11 articles) stand out. It is worth mentioning that these studies introduced the debates on sustainable diets in the late 1980s and were especially important until 2010, when studies on the environmental impact of livestock farming also became relevant. The production of meat, especially cattle, started to be considered a great challenge to be faced. This is due not only to its high greenhouse gases emissions, but also to the need for large tracts of land to grow vegetables for the animal feed production (based on soybean and corn), causing deforestation and loss of biodiversity and making it potentially harmful to the environment. Therefore, studies were conducted aiming to reduce this impact by reviewing issues such as grazing, genetic improvement, alternative production of protein sources, such as legumes, algae, insect breeding, artificial meat development, and others.

With regards to dairy, other possibilities were also foreseen, such as the production of beverage from oats. Regarding fish and seafood, concerns about the use and contamination of water and the techniques of production and fishing have been discussed. Furthermore, water and soil contamination was also the focus of research related to the use of pesticides and fertilizers in crops.

Organic foods are within this scope of production, interacting with consumption. In this regard, a study ${ }^{23}$ investigates the impact of the change of food production to $100 \%$ organic in England and Wales, trying to identify how much this would be feasible for internal supply. In addition to this, there are concerns inherent in the purchase of organics and its determinants in institutional environments such as schools.

Finally, studies on wastage are worth mentioning, for it pervades the entire production chain, from production to disposal by the consumer. Out of the studies relating food wastage to sustainable diets, five were identified problematizing the consumers' behaviors regarding this issue. Other studies seek to identify what is wasted, the causes, what can be done to avoid it, and the role of retailers and processors in this regard.

\section{Health dimension}

As seen in topic 3.2, this dimension has been analyzed through the bias of the nutritional adequacy of sustainable diets, but it is also linked to other aspects such as how obesity, noncommunicable diseases (diabetes, cardiovascular diseases, cancers, etc.), nutritional deficiencies, and other public health issues relate to environmental impacts and economic issues. These studies identify that the usual diets have caused, at the same time, a threefold problem - impaired public health, impact on the environment and increased public costs to tackle these issues ${ }^{24,25}$.

One of the scientific fields directly involved in this discussion is Nutrition. Therefore, publications address the role of the nutritionist to change this scenario by reviewing their everyday practice and academic curricula, adding the sustainable food system matter to their praxis.

\section{Economic dimension}

Articles that studied the economic dimension of sustainable diets sought not only to understand the cost of sustainable diets and how they determine their consumption, but also other factors. It is worth mentioning the impact that certain foods have on the environment and public health and how much it means in terms of public and private spending with cardiovascular diseases, for example, or with climate change. Based on this concern, some studies address taxation on foods like sugary drinks and products of animal origin and subsidies to more appropriate food. These studies use scenario simulations and mathematical models to verify the impact of these actions on the decrease or increase of con- 
sumption of certain foods and their effects on health and environment. Other studies investigate how much more consumers would be willing to pay for products claimed as "sustainable", such as meat production with less water.

Another group of studies focuses on the role of industry, retail and services in the face of global challenges and how these sectors can influence food production and consumption to encourage a more sustainable food system, or how they can review their actions to set up initiatives that address these concerns.

The studies also seek to identify economic gains or losses in cases of changes in food patterns or food production for patterns considered to be more sustainable. In the wake of these concerns, a study ${ }^{26}$ that evaluated food consumption coupled with the sustainable development and economic growth of 77 countries stands out. This study pointed out how developed and developing countries would be affected given that, for instance, increased consumption of meat favors economic growth whereas this consumption should be decreased for the sake of the planet's sustainability. How to overcome these types of impasse?

\section{Sociocultural dimension}

Among the discussions related to the sociocultural dimension, few articles dealing with specific diets such as the Mediterranean, Nordic, Dutch, Chinese, Indian, and others, focus on this aspect, as in most cases they emphasize environmental and health analyses. However, they all have an important component, that is, the cultural aspect, including its own cuisine, history, culinary, eating habits, their tastes. In this regard, studies have pointed out that a strategy to reduce meat consumption would be the inclusion of insects in diets. This recommendation faces a strong cultural contestation, since insects in certain cultures can be considered as food, whereas in the western diets, they are strongly rejected as food. In addition, the high consumption of meat in countries such as Argentina and Brazil is largely due to habits rooted in their cultures, which makes the challenge of making changes or minimizing their intake even more problematic.

Beyond their cultural matters, studies within this dimension address social issues, such as the role of society or social actors in the necessary changes. Thus, as local agriculture is supported by the community as consumers, actors like farmers, food industry and state engage in proj- ects, programs, actions, policies aimed at more sustainable systems and diets. Articles discuss this theme by raising issues such as ethics, morality, politicized consumption, social inclusion and the responsibility of the various actors.

\section{Politics and Governance}

This item is linked to all dimensions, for food policies are intersectoral and the sustainable diets theme will be an increasingly important social agenda in the coming years. Thus, researchers have also been dedicated to the analysis of existing and needed policies to address this challenge and the difficulties in bringing environmental, agricultural, health and economic issues closer to each other.

In this group of studies, there are those which propose the development of a set of policy tools to promote sustainable diets, or the use of the sustainable diets approach to evaluate the integration of existing policies. As we previously touched upon when discussing consumption, policies regarding nutritional recommendations and dietary guidelines have been worked out, posing new challenges to nutrition science regarding what is meant by an "adequate" diet given the contemporary context. In addition to these interventions, policies related to taxation and subsidies have also been proposed in the literature. Other articles focus on public food procurement policies, considering the potential role of the state in fostering green or sustainable markets.

In the studies discussing governance ${ }^{27,28}$, the central argument is that a sustainable food system can only be achieved by shifting the level of socioeconomic governance from the private-sector control to the state control. They suggest that it would require a full range of interventions, including 'hard' measures such as regulations and fiscal instruments, as well as approaches such as voluntary agreements, awareness-raising, and education. For the authors, greater regulation of multinational corporations is needed, along with a more important role for publicly supported research and development, agricultural extension, and other initiatives.

\section{Metrics, measures and models to analyse sustainable diets}

Finally, we brought together a group of papers aiming to problematize the methodologies used to analyze sustainable diets. Each of the di- 
mensions considered has its own metrics, measures and models, which already indicates the difficulties in bringing together suitable methods to achieve similar objectives.

One of the most widely used methods to evaluate the environmental impact of food and diets is the life cycle assessment. Studies that approach it are characterized by literature reviews, or discussions about its accuracy, subjectivity, and its ability to measure the complexity of the current food system. Some of these concerns arise from the fact that environmental resources and burdens (water use, land degradation, and eutrophication) are highly context-dependent. Therefore, food Life Cycle Assessment (LCA) depends on local data, since data of other countries are not the same as Brazil's, for instance. Furthermore, according to Drewnowski et al. ${ }^{19}$, the LCA data of the food products from countries like USA and France are extremely limited. However, the same authors mention that other methodologies are needed to evaluate the environmental aspect of food processing, packaging, wastage, and waste generated.

Another issue raised is the availability of information, such as data on food prices at the national level, population's dietary patterns, epidemiological information, and socioeconomic determinants of food choice. As a result, Drewnowski's ${ }^{19}$ research group noted that existing studies on sustainable food and diets produced only partial and fragmented responses. The lack of empirical data to build and test models is a challenge.

On the other hand, researchers have been working on these methodological matters, such as the study by Gazan et $\mathrm{al}^{29}$, which proposes to create in France a methodology that will gather analysis metrics for each dimension of sustainable diets in a single database. Others have been using and developing other instruments, such as remote sensing to capture the use of water in some crops such as wheat, rice and corn at local, regional and global levels.

\section{Sustainable diets as a new and challenging research agenda in Brazil}

When searching the bibliographic databases with the uniterms 'sustainable $\operatorname{diet}(\mathrm{s})$ ' in Portuguese, 14 papers were written in Brazil about or tangent to this discussion (besides the five works previously mentioned which were published in international journals, totaling 19 works). Out of these 14 works, six were dissertations or the- ses from the University of São Paulo (USP, from 2014 to 2017), two dissertations from the Federal University of Santa Catarina (UFSC, 2015 and 2017), and one dissertation from the Federal University of Rio Grande do Sul (UFRGS, 2017). Out of the five articles written in total, one was published in 2012, two in 2013, one in 2017, and the latest one in 2018.

The topics covered are: label analysis (two articles); agrobiodiversity, diversity (three articles); analysis of institutional menus and food services - school feeding (three articles); discussion on the relationship between health, environment and food (two articles); rural tourism (one article); ultra-processed food (one article); dietary patterns and water footprint (one article); organic food prices and distribution channels (one article). Out of the five papers published internationally, two were from the USP (2012 and 2016) on meat intake and its impact on the environment and nutritional quality; two were from the Federal University of Santa Maria (UFSM), on the association between obesity, environmental impacts, food and health costs (2015 and 2018), and the latest one, from the University of Campinas in 2018, on consumer perceptions on healthy/sustainable/unsustainable diets.

As previously seen, the USP has been the main institution in these researches, also taking into account that the elaboration of the current Dietary Guideline for the Brazilian Population ${ }^{30,31}$ was, to a large extent, planned by its researchers. This Guide is an international benchmark as an instrument that added to nutritional recommendations, concerns about the food system, and sustainability of diets.

Nevertheless, this scenario shows that the country is beginning its academic interest in this subject, but it still is a long way from having a consistent engagement when compared to European countries. The research agenda on this theme in Brazil is to be explored from all aspects that have been identified in international research.

\section{Conclusions}

The discussion on sustainable diets is recent but is on the rise. The idea is that our diets should be set up to have the potential to recalibrate the current food system that compromises the ability to produce food in the future and can have irreversible effects on the ecosystem and health. It is important to recognize that the myth of the twentieth century, that humans could eat what 
and what they wanted without consequences for anyone but for themselves, must be overturned because the planet has its limits.

The analysis of the articles on this topic demonstrates a variety of studies that mainly addressed: contributions to the construction of this concept; analysis of diets and foods and their relation with the five dimensions of sustainable diets; understanding of consumer behavior; analysis of the environmental impacts of agriculture; analysis of economic and socio-cultural aspects and their relation with the achievement of a sustainable diet; relationship of health with other aspects of diet (environment) and not only nutritional; discussion of effective policies and forms of governance; search for efficient methods to carry out these research.

The state of the art on this theme described in this article opens many perspectives of studies in Brazil. For example, about methodology, the life cycle assessments of food are almost non-existent, and therefore there is no database includ- ing the emission of gases, use of land and water of the food that is produced/consumed, which practically precludes more accurate investigations on the environmental impacts of diets in the country.

In addition, although there have been in Brazil more discussions on food and nutrition security and sustainable development which are aggregating proposals for sustainability ${ }^{32-33}$, the role of diets is still marginalized, which requires more attention and strength as a purpose of broader and more in-depth research and not just tangential, as in most published works.

Therefore, this research area is open to a wide range of fields, such as Nutrition, Agronomy, Veterinary Medicine, Biology, Ecology, Sociology, Economics, Engineering, and others. Moreover, we highlight the Nutrition field, where this debate should be added to its range of subjects for teaching, research and extension activities, given the challenge of answering the question 'What is an adequate diet in the $21^{\text {st }}$ century?' 


\section{References}

1. Instituto Brasileiro de Geografia e Estatística (IBGE). Pesquisa de Orçamentos Familiares 2008-2009 - POF. Rio de Janeiro: IBGE; 2010.

2. Food and Agriculture Organization (FAO). The state of food and agriculture: leveraging food systems for inclusive rural transformation. Rome: FAO; 2017.

3. Barilla Center for Food and Nutrition. Eating in 2030: trends and perspectives. Rome; 2017.

4. Instituto Brasileiro de Geografia e Estatística (IBGE) Indicadores de Desenvolvimento Sustentável. Rio de Janeiro: IBGE; 2012.

5. High Level Panel of Experts on Food Security and Nutrition (HLPE). Nutrition and food systems: report by the high level panel of experts on food security and nutrition of the committee on world food security. Rome; 2017.

6. International Food Policy Research Institute (IFPRI). Global Food Policy Report. Washington, DC: International Food Policy Research Institute; 2018.

7. Garnett T. What is a sustainable healthy diet? A discussion paper. Food Climate Research Network; 2014.

8. Godfray C. O desafio de alimentar nove mil milhões de pessoas em 2050. In: Santos JL, Carmo I, Graça P coordenadores. O futuro da alimentação: ambiente, saúde e economia. Lisboa: Fundação Calouste Gulbenkian; 2013. p.18-32.

9. Watts N, Amann M, Ayeb-Karlsson S, Belesova K, Bouley T, Boykoff M, Byass P, Cai W, Campbell-Lendrum D, Chambers J, Cox PM, Daly M, Dasandi N, Davies M, Depledge M, Depoux A, Dominguez-Salas P, Drummond P, Ekins P, Flahault A, Frumkin H, Georgeson L, Ghanei M, Grace D, Graham H, Grojsman R, Haines A, Hamilton I, Hartinger S, Johnson A, Kelman I, Kiesewetter G, Kniveton D, Liang L, Lott M, Lowe R, Mace G, Odhiambo Sewe M, Maslin M, Mikhaylov S, Milner J, Latifi AM, Moradi-Lakeh M, Morrissey K, Murray K, Neville T, Nilsson M, Oreszczyn T, Owfi F, Pencheon D, Pye S, Rabbaniha M, Robinson E, Rocklöv J, Schütte S, Shumake-Guillemot J, Steinbach R, Tabatabaei M, Wheeler N, Wilkinson P, Gong P, Montgomery H, Costello A. The Lancet Countdown on health and climate change: from 25 years of inaction to a global transformation for public health. Lancet 2017; 30(1):1-50.

10. Soares CB, Hoga LAK, Peduzzi M, Sangaleti C, Yonekura T, Silva DRAD. Revisão integrativa: conceitos e métodos utilizados na enfermagem. Rev Esc Enferm USP 2014; 48(2):335-345.

11. Gussow J, Clancy K. Dietary guidelines for sustainability. J Nutr Educ 1986; 18(1):1-5.

12. Herrin M, Gussow JD. Designing a sustainable regional diet. J Nutr Educ 1989; 21(1): 270-275.

13. Feenstra G. Local food systems and sustainable communities. J Alternative Agric 1997; 12(1): 28-26.

14. Peters J. Community food system: working toward a sustainable future. J Am Diet Assoc 1997; 97(9): 955956.

15. Wahlqvist ML, Specht RL. Food variety and biodiversity: Econutrition. Asia Pac J Clin Nutr 1998; 7(3/4): 314-319.

16. Food and Agriculture Organization (FAO). International Scientific Symposium: biodiversity and sustainable diets - United Against Hunger. Rome: FAO; 2010.
17. Meybeck A, Gitz V. Sustainable diets within sustainable food systems. Proc Nutr Soc 2017; 76(1): 1-11.

18. Mason P, Lang T. Sustainable diets: how ecological nutrition can transform comsumption and the food system. UK: Routledge; 2017.353p.

19. Drewnowski A. and The ecosystem inception team The Chicago consensus on sustainable food systems science. Front Nutr 2018; 4(1):1-6.

20. Johnston JL, Fanzo JC, Cogill B. Understanding Sustainable Diets: a descriptive analysis of the determinants and processes that influence diets and their impact on health, food security, and environmental sustainability. American Society for Nutrition. $A d v$ Nutr 2014; 5(1): 418-429.

21. Auestad N, Fulgoni VL. What current literature tells us about sustainable diets: emerging research linking dietary patterns, environmental sustainability, and economics. American Society for Nutrition. Adv Nutr 2015; 6: 19-36.

22. Behrens P, Kiefte-de Jong JC, Bosker T, Rodrigues JFD, de Koninga A, Tukker A. Evaluating the environmental impacts of dietary recommendations. PNAS 2017 114(51): 13412-13417.

23. Smith LG, Jones PJ, Kirk GJD, Pearce BD, Williams AG. Modeling the production impacts of a widespread conversion to organic agriculture in England and Wales. Land Use Policy 2018; 76(1): 391-404.

24. Abbade EB. The relationships between obesity-increasing risk factors for public health, environmental impacts, and health expenditures worldwide. Manage Environ Quality 2018; 29(1):131-147.

25. Rao ND, Mina J, De Friesb R, Ghosh-Jerathc S, Valina $\mathrm{H}$, Fanzo J. Healthy, affordable and climate-friendly diets in India. Glob Env Change 2018; 49(1):154-165.

26. Marques AC, Fuinhas JA, Pais D. Economic growth, sustainable development and food consumption: evidence across different income groups of countries. Journal of Cleaner Production 2018; 196(1): 245-258.

27. Vinnari M, Tapio P. Sustainability of diets: from concepts to governance. Ecol Econ 2012; 74(1): 46-54.

28. Garnett T. Food sustainability: problems, perspectives and solutions. Proceedings of the Nutrition Society 2013; 72(1): 29-39.

29. Gazan R, Barré T, Perignon M, Maillot M, Darmon $\mathrm{N}$, Vieux F. A methodology to compile food metrics related to diet sustainability into a single food database: application to the French case. Food Chemistry 2018; 238(1): 125-133.

30. Brasil. Ministério da Saúde(MS). Secretaria de atenção à saúde. Departamento de atenção básica. Guia alimentar para a população brasileira. Brasília: MS; 2014.

31. Monteiro CA, Cannon G, Moubarac JC, Martins APB, Martins CA, Garzillo J, Canella DS, Baraldi LG, Barciotte M, Louzada MLC, Levy RB, Claro RM, Jaime PC. Dietary guidelines to nourish humanity ant the planet in the twenty- first century. A blueprint from Brazil. Public Health Nutr 2015; 18(13):2.311-2.322.

32. Ribeiro H, Jaime PC, Ventura D. Alimentação e sustentabilidade. Estud Av 2017; 31(89): 185-198. 
33. Oliveira NRF, Jaime PC. O encontro entre o desenvolvimento rural sustentável e a promoção da saúde no Guia Alimentar para a População Brasileira. Saude Soc 2016; 25(4):1108-1121.

Article submitted 11/09/2018

Approved 01/08/2019

Final version submitted 03/08/2019

Chief Editors: Romeu Gomes, Antônio Augusto Moura da Silva 